\title{
Demand for Money, Financial Innovation and Money Market Disequilibrium
}

\author{
Dr. Sadia Safdar ${ }^{1}$, Ms. Azra Khan ${ }^{2}$ \\ ${ }^{1}$ (Assistant professor, FUUAST, School of Economic Sciences, Federal Urdu University of Arts, Science and \\ Technology, Islamabad, Pakistan. \\ ${ }^{2}$ (Lecturer \& Ph.D Scholar, FUUAST, School of Economic Sciences, Federal Urdu University of Arts, Science \\ and Technology, Islamabad, Pakistan.
}

\begin{abstract}
This study examines the impact of financial innovation on money demand and to analyze the impact of money market disequilibrium on output gap using co integration modeling.

After the confirmation of ADF result we use the cointegration technique for our first model and concluded that both the numbers of ATM and cards are negatively related to the demand for money. So in order to control the money demand we should increase the ATMs. The results also confirm that there exists a quantity theory with the inclusion of financial innovation in the money demand function. Our second model is related to the money market disequilibrium and the output gap. The findings of this second model shows that money market disequilibrium leads to wider the output gap.
\end{abstract}

Key Words: Money Demand, Financial Innovation, ATM, Money Market Disequilibrium, Output gap

\section{INTRODUCTION:}

The importance of a well-specified demand for money to the implementation of monetary policy is well recognized in the existing literature. Goldfeld (1994) considers that the relation between the demand for money and its main determinants is an important building block in macroeconomic theories and is a crucial component in the conduct of monetary policy. As a result, the demand for money is one of the topical issues that has attracted the most attention in the literature both on developed and developing countries. In the context of developed countries it is argued that disequilibrium in the demand for money (defined as the difference between the real money stock and the long-term equilibrium real money stock) may affect the efficacy of interest rate policy in the long run via its impact on output gap and/or inflation.

There are a number of studies that highlight the importance of the demand for money in developed countries because the "real money gap" (the resulting residuals from the money demand function) helps to forecast future changes in the output gap and/or inflation (see, inter alia, Laidler, 1999, Gerlach and Svensson, 2002, and Siklos and Barton, 2001).

A consensus among economists is emerging in support of the view that it is not a valid argument to focus exclusively on a single policy instrument and entirely neglect an important information variable because both the interest rate and monetary aggregates do matter in policy formation. Given that the output gap is deemed to be an important factor in determining the official interest rate (as supported by the Taylor rule), then one can conclude that the real money gap indirectly affects the interest rate via its direct influence over the output gap and/or inflation. Therefore, a well functioning and stable money demand function is still important in this era of inflation targeting. It is essential to track both the interest rates and the money stock in order to assess precisely how monetary policy impacts upon the economy. Laidler $(1999$, p.26) in the context of the OECD countries, which pursue inflation-targeting policy, posits that monetary aggregates should not be used "as the only target of monetary policy.

Economic performance of the country significantly depends on efficiency of monetary policy. Monetary policy can be implemented in several forms. Generally, all forms choose efficient control variable or several variables and by adjusting these variable(s), central banks attempt to reach desired target levels of aggregate economic outcomes such as inflation, economic growth, employment etc. Inflation targeting regime is a form of implementation of monetary policy and it has been popular among developed and developing countries. Recent studies such as Taylor (1993), McCallum (1999) explored simple policy rules as guides for monetary policy. These rules use different policy instruments to attain the desired level of inflation and economic growth rates. Particularly, well known Taylor (1993) rule uses short term interest rates as a policy instrument to attain the desired level of inflation and Gross Domestic Product (GDP) growth rates. This policy rule assumes that short term interest rates are efficient policy instruments and all channels of transmission are sufficiently developed. Though the Taylor rule is very simple and intuitive, the rule's prominence comes from its ability to explain federal funds' rate movements, in post 1986. Questions have been raised about whether 
policy makers could actually implement a Taylor rule to set policy. McCallum (1999) stresses that, implementation of Taylor rule is infeasible, because it is based on information unavailable to policy makers when policy is set. Thus, he proposed his simple policy rule where policy instrument is monetary aggregate. According to his rule, central banks adjust monetary aggregate to attain desired level of nominal growth rate of GDP.

Our aim is to investigate the stability of money demand function when the financial innovation is introduced for example the use of credit cards and ATM machines etc by taking the low income, middle income and high income countries. It is expected that in the high income countries there is extensive use of credit cards and ATM machines due to which the demand for money is reduced. But there is opposite case for the developing countries or the middle and low income countries because in these countries credit cards and ATM machines are not used much. So at that point the issue arises that what kind of monetary policy should be used after the introduction of financial innovation in these countries. To answer that question we estimate the Taylor rule and McCallum rule for the seven countries to conclude that what policy the policy makers should actually implement.

The main objectives of our study are:

1. To investigate the impact of financial innovation on demand for money in Pakistan.

2. To provide the empirical evidence supporting the view that disequilibrium in the money market can widen the output gap in Pakistan, which has received considerable attention in developed countries (e.g. McCallum, 2001) but not in the context of developing countries like Pakistan.

\section{LITERATURE REVIEW:}

The stability of money demand function in Turkey for 1950-2002 is examined ${ }^{1}$. Using a recent single co integration technique, ARDL, they are able to demonstrate that there is a long-run relationship between the narrow M1 money aggregate and its determinants: national income, interest rate and exchange rates. It is also tried to incorporate the short and long-run dynamics of money demand function in order to perform a more robust account of the stability of money demand function. To this end, the CUSUM and CUSUMSQ stability tests are utilized and they indicate that there exists a stable money demand function. These results suggest that it is possible to use the narrow money aggregate as target of monetary policy in Turkey. As far as the Turkish central bank's monetary policy is concerned, they assume that stability of a money demand function will reduce the uncertainty associated with the financial environment and will increase the credibility of its ability to pursue a monetary target.

The money demand functions can enhance our understanding of the behavior of key monetary aggregates. A specific application of our narrow money demand model is to explain the relatively unexpected movements in narrow money during the past several years ${ }^{2}$. Findings suggest that the sharp increase in M1 between 2002 and 2004 was associated with the non-linear effects of near-zero interest rates, which brought about a significant shift from term deposits towards demand deposits during this period. With interest rates rising since the beginning of 2005, there has been a reversal of the above process, or a rapid shift from liquid deposits back to the less liquid deposits. This implies the cost of funds for banks has been boosted not only by the rise in deposit rates, but also by the shifting of deposits towards the less liquid. Separately, the broad money demand function presented is consistent with previous similar studies, showing that the money demand relationship is quite stable over time. The model can be used to construct a money gap indicator, which is found to be useful in explaining inflation and output. This can be useful to the understanding of how an autonomous increase in broad money (caused by capital inflows, for instance) may affect inflation and output growth.

The cointegration analysis indicates that there is a long run relationship for both base money and M2 in Uganda $^{3}$. In both cases, the income elasticity is found to be close to unity, a result that is consistent with the quantity theory of money. The relative interest rate and exchange rate elasticities are found to be negative, which is also consistent with economic theory. However in both cases, the exchange rate elasticity is higher than the interest rate elasticity, suggesting that the exchange rate channel is stronger than the interest rate channel in the monetary policy transmission mechanism. The short-run elasticities are also to a large extent consistent with economic theory. Further, there is no sufficient evidence in support of the instability of the money demand functions, which implies that monetary growth is a good predictor of future inflation and real output in Uganda.

\footnotetext{
${ }^{1}$ Halicioglu, f. and Ugur (2005)

${ }^{2}$ Shek, Tsang(2006)

${ }^{3}$ Opolot.(2007)
} 
A model of money demand for retail transactions over the period 1960-1999 is estimated, where with the standard variables of the money demand theory (GDP and interest rate) the other variables like effect of bank-cards as a potential for cash substitution are added ${ }^{4}$. Information concerning the card payment infrastructure, i.e. the number of outstanding cards, the number of shops with card terminal and the number of ATMs in Belgium is used. The estimation allows identifying two stable cointegration relationships. It is found that over the period 1960-1999 card payments have contributed to the reduction of money demand. This is a strong finding if one thinks that cards started to be used for retail payments in Belgium only in the late Seventies. In particular the elasticity of money demand to ATMs has a negative sign, meaning that ATMs contributed significantly to money reduction. Similarly the number of merchants with POS terminal also had an impact on cash substitution. The evidence for the number of cards is less clear but this could be due to a multicollinear effect between the number of cards and the number of merchants accepting them. When cointegration holds, if there is any shocks that causes disequilibrium, there exists a well-defined short-term dynamic adjustment process such as the error correction model mechanism that pushes back the system towards the long run equilibrium. There is a long-run relation between currency and cards. However, since the coefficient of the error correction term is small, it can be argued that currency responds very slowly to disequilibria. Finally, Future developments of money demand with respect to card payments are forecasted by simulating impulse response functions. The identification problem is solved using the Cholesky decomposition, which implies an ordering of the variables. On the basis of finding one could argue that the card payments are substitutes for notes and coins and that the substitution process is already taking place. It cannot be denied that everywhere in Europe the use of electronic money, the most advanced retail payment instrument, has taken off more slowly than what was expected. An explanation could be that consumers and merchants adapt their payment habits rather slowly. Nevertheless the change towards a more efficient and convenient payment system is gradually taking place.

Relationships among different definitions of M1 (net and gross), output, prices and the 90-day paper rate are examined at monthly and quarterly frequencies and over different sample periods ${ }^{5}$. The JohansenJuselius multivariate approach used here allows for the specification of exogenous variables that improve the estimates of the short-run dynamics and help ensure the stability of the systems while enhancing the estimates of the cointegrating relationships themselves. By comparing the parameter estimates and dynamic behavior of the estimated systems with theoretical priors, this work identifies unique, well-specified, and stable cointegrating relationships among M1, output, prices and an interest rate that has the properties of a well-behaved moneydemand function. Parameter estimates generally imply the weak erogeneity of output and interest rates, but reject this hypothesis for prices and inflation. The implication of this is that output and interest rates do not adjust to offset monetary disequilibria, that is, a deviation of actual M1 from money-demand. All the adjustment to return the economy to monetary equilibrium comes from fluctuations in money and prices. In particular, when M1 is above its long-run demand, money tends to fall and prices rise in order to restore equilibrium. However, this does not preclude the possibility that changes in the stock of money can still have short-run real effects.

\section{MODELS:}

The recent study postulates the demand for money as a function of the inflation rate, short run interest rates, real income and financial innovation.

\subsection{Model I:}

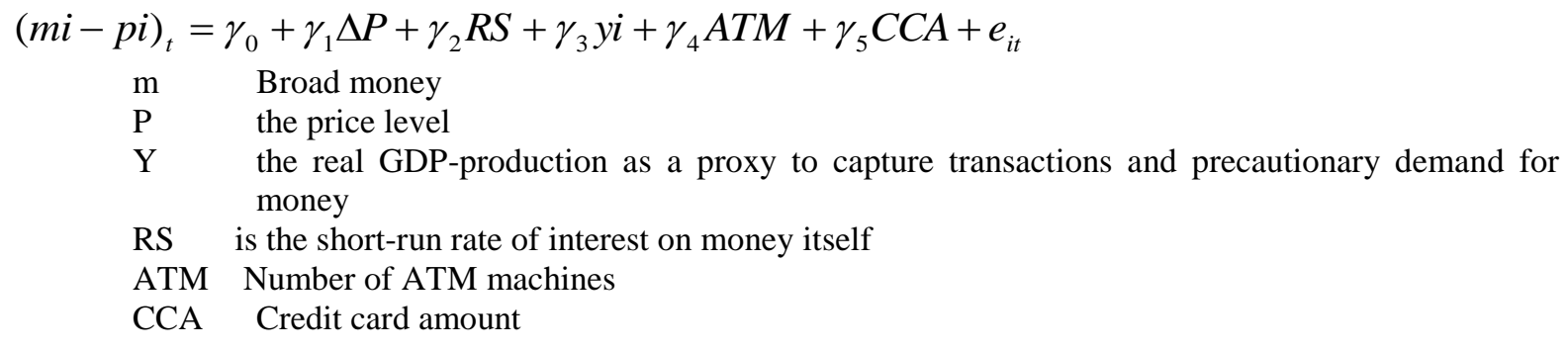

\footnotetext{
${ }^{4}$ Rinaldi (2001)

${ }^{5}$ Hendry (1995)
} 
All variables shown are in natural logarithms. As a result, $\gamma_{1}$ and $\gamma_{3}$ denote the short-run inflation and income elasticities of the demand for money, whereas $\gamma_{2}$ are short-run semielasticities of RS with respect to money demand, respectively.

The rate of inflation, or $\Delta \mathrm{p}_{\mathrm{t}}=\ln \left(\mathrm{P}_{\mathrm{t}}\right)-\ln \left(\mathrm{P}_{\mathrm{t}-1}\right)$, is considered as a proxy to measure the return on holdings of goods (including foreign currencies), and its coefficient should be negative, i.e. $\gamma_{1}<0$, as goods (e.g real estate and other currencies) are an alternative to holding domestic currency. According to Ericsson $(1998,309)$, the exclusion or inclusion of inflation in this equation is a matter of empirical investigation. It is also expected that the coefficient for the short-run rate of interest (the deposit interest rate or RS) is negatively (or $\gamma_{2}<0$ ) correlated with money demand. The expected sign and magnitude of the coefficient for $\mathrm{y}$ is as follows: if $\gamma_{3}=1$, the quantity theory applies; if $\gamma_{3}=0.5$, the Baumol-Tobin inventory-theoretic approach is applicable; and if $\gamma_{3}>1$, money can be considered a luxury. According to Ball (2001), an income elasticity of less than unity has a number of implications for monetary policy. For instance, one may conclude that the Friedman rule is not optimal in this case and the supply of money should grow more sluggishly than output to achieve the goal of price stability (Ball, 2001, p.36).

\subsection{Model II:}

Attention is now directed to the relationship between the lagged disequilibrium in the money market and the output gap. The lagged disequilibrium in the money market can be regarded as a useful information variable and is proxied by the resulting residuals $\left(e_{i t-l}\right)$. The output gap for country is measured by the difference between real actual GDP and the real potential GDP or $\left(Y_{i t}-Y^{p}{ }_{i t}\right)$.The potential output is calculated by employing the Hodrick and Prescott (HP) filter (Hodrick and Prescott, 1997) that is widely used in the literature (de Brouwer, 1998 and Haltmaier, 2001) to decompose a time series into trend and cyclical components as well as the computation of potential output (yp).

$$
\left(Y_{i t}-Y^{p}{ }_{i t}\right)=\alpha_{1}+\beta_{1} e_{i t-1}
$$

The above equation specifies the output gap as a function of the lagged disequilibrium in the money market (or eit-1). It is expected that the lagged disequilibrium in the money market can lead to wider output gap.

\subsection{Unit Root Test:}

\section{Discussion of Results:}

\begin{tabular}{|c|c|c|c|c|c|c|}
\hline \multirow[t]{2}{*}{ variables } & \multirow[t]{2}{*}{ lags } & \multicolumn{2}{|c|}{ level } & \multirow[t]{2}{*}{ lags } & \multicolumn{2}{|c|}{$1^{\text {st }}$ difference } \\
\hline & & intercept & $\begin{array}{ll}\text { Trend } & \& \\
\text { intercept } & \end{array}$ & & intercept & Trend \& intercept \\
\hline Md & 1 & $\begin{array}{l}0.99 \\
(2.92)\end{array}$ & $\begin{array}{l}2.13 \\
(3.58)\end{array}$ & 0 & $\begin{array}{l}4.28^{*} \\
(2.97)\end{array}$ & $\begin{array}{l}4.60^{*} \\
(3.58)\end{array}$ \\
\hline$\Delta \mathrm{p}$ & 1 & $\begin{array}{l}0.6653 \\
(2.9705)\end{array}$ & $\begin{array}{l}3.8392 \\
(3.5867)\end{array}$ & 1 & $\begin{array}{l}3.7040 * \\
(2.9850)\end{array}$ & $\begin{array}{l}3.949358 * \\
(3.5943)\end{array}$ \\
\hline ATM & 0 & $\begin{array}{l}1.64 \\
(2.97)\end{array}$ & $\begin{array}{l}2.41 \\
(3.58)\end{array}$ & 0 & $\begin{array}{l}5.88^{*} \\
(2.97)\end{array}$ & $\begin{array}{l}5.10^{*} \\
(3.58)\end{array}$ \\
\hline $\mathrm{y}$ & 0 & $\begin{array}{l}0.400 \\
(2.97)\end{array}$ & $\begin{array}{l}2.24 \\
(3.58)\end{array}$ & 0 & $\begin{array}{l}5.24^{*} \\
(2.97)\end{array}$ & $\begin{array}{l}5.10^{*} \\
(3.58)\end{array}$ \\
\hline $\mathrm{CCA}$ & 0 & $\begin{array}{l}1.93 \\
(2.97)\end{array}$ & $\begin{array}{l}2.12 \\
(3.57)\end{array}$ & 0 & $\begin{array}{l}5.48^{*} \\
(2.97)\end{array}$ & $\begin{array}{l}5.60^{*} \\
(3.58)\end{array}$ \\
\hline Ygap & 0 & $\begin{array}{l}3.42 * \\
(2.97)\end{array}$ & $\begin{array}{l}3.96^{*} \\
(3.57)\end{array}$ & - & - & - \\
\hline $\mathrm{RS}$ & 1 & $\begin{array}{l}2.917465 \\
(2.9750)\end{array}$ & $\begin{array}{l}2.791300 \\
(3.5867)\end{array}$ & 0 & $\begin{array}{l}4.1374 * \\
(2.9750)\end{array}$ & $\begin{array}{l}4.1131 * \\
(3.5867)\end{array}$ \\
\hline $\mathrm{r}^{*}$ & 2 & $\begin{array}{l}0.181602 \\
(2.9798)\end{array}$ & $\begin{array}{l}0.22 \\
(3.67)\end{array}$ & 1 & $\begin{array}{l}2.6422 * \\
(1.9546)\end{array}$ & $\begin{array}{l}2.440511^{*} \\
(3.5943)\end{array}$ \\
\hline
\end{tabular}

To examine whether a time series have unit root we have used Augmented Dickey-Fuller (ADF) unit root test. The *on the value shows that the values are stationary at $5 \%$ level of significance. All the variables are stationary at $1^{\text {st }}$ difference except the output gap which is stationary at level. Therefore the most appropriate technique for model one is Co-integration while for model II we use the OLS.

\section{2. $\quad$ Results of Model 1:}

The first step of this test is to estimate the VAR to choose the lag length of the model. The maximum lag length of our model is 2. For the estimation of model I we are using the trace statistic and Max-Eigen Statistic in order to find the long run relationships. By using the Trace Statistic we have the following results. 


\begin{tabular}{|l|l|c|c|c|c|}
\hline Ho & H1 & Eigenvalue & $\begin{array}{c}\text { Trace } \\
\text { Statistic }\end{array}$ & $\begin{array}{c}0.05 \\
\text { Critical Value }\end{array}$ \\
\hline $\mathrm{r}=0^{*}$ & $\mathrm{r} \geq 1$ & 0.997945 & 384.6936 & 103.8473 & 0.0000 \\
\hline $\mathrm{r} \leq 1^{*}$ & $\mathrm{r} \geq 2$ & 0.952734 & 199.0706 & 76.97277 & 0.0000 \\
\hline $\mathrm{r} \leq 2^{*}$ & $\mathrm{r} \geq 3$ & 0.854992 & 107.5118 & 54.07904 & 0.0000 \\
\hline $\mathrm{r} \leq 3^{*}$ & $\mathrm{r} \geq 4$ & 0.536445 & 49.58283 & 35.19275 & 0.0008 \\
\hline $\mathrm{r} \leq 4^{*}$ & $\mathrm{r} \geq 5$ & 0.458517 & 26.51793 & 20.26184 & 0.0060 \\
\hline $\mathrm{r} \leq 5$ & $\mathrm{r} \geq 6$ & 0.236993 & 8.114625 & 9.164546 & 0.0788 \\
\hline
\end{tabular}

Trace test indicates 5 cointegrating eqn(s) at the 0.05 level

* denotes rejection of the hypothesis at the 0.05 level

By using the Max-Eigen Statistic we have the following results

\begin{tabular}{|l|l|c|c|c|c|}
\hline Ho & $\mathrm{H} 1$ & Eigenvalue & Max-Eigen & $\begin{array}{c}0.05 \\
\text { Critical Value }\end{array}$ & Prob.** \\
\hline $\mathrm{r}=0^{*}$ & $\mathrm{r}=1$ & 0.997945 & Statistic & 40.95680 & 0.0001 \\
\hline $\mathrm{r} \leq 1^{*}$ & $\mathrm{r}=2$ & 0.952734 & 91.55888 & 34.80587 & 0.0000 \\
\hline $\mathrm{r} \leq 2^{*}$ & $\mathrm{r}=3$ & 0.854992 & 57.92893 & 28.58808 & 0.0000 \\
\hline $\mathrm{r} \leq 3^{*}$ & $\mathrm{r}=4$ & 0.536445 & 23.06491 & 22.29962 & 0.0390 \\
\hline $\mathrm{r} \leq 4^{*}$ & $\mathrm{r}=5$ & 0.458517 & 18.40330 & 15.89210 & 0.0198 \\
\hline $\mathrm{r} \leq 5$ & $\mathrm{r}=6$ & 0.236993 & 8.114625 & 9.164546 & 0.0788 \\
\hline
\end{tabular}

Max-eigenvalue test indicates 5 cointegrating eqn(s) at the 0.05 level

* denotes rejection of the hypothesis at the 0.05 level

Estimated Co-integrated Coefficients:

Dependent variable: $\mathrm{Md}$

\begin{tabular}{|c|c|c|c|}
\hline Variables & Coefficients & Std. Error & T Statistics \\
\hline C & 10.05891 & $(1.27767)$ & 7.8728 \\
\hline CMR & -0.012718 & $(0.02554)$ & -0.4979 \\
\hline ATM & -0.139577 & $(0.06154)$ & -2.2680 \\
\hline CCA & -0.400701 & $(0.04217)$ & -9.5020 \\
\hline Y & 1.031692 & $(0.42664)$ & 2.4181 \\
\hline INF & -0.238974 & $(0.12217)$ & -1.9660 \\
\hline
\end{tabular}

The above results show that the income is positively related to the demand for money because when people have more income they demand more money. Where the interest rate is negatively related to the money demand because with the lower interest rate people prefer to hold money in their hands. ATM reflects the effect of a substitute cash provision method and could be positive or negative: as the number of ATMs increases, cash is easier to get, so people use it more. In case of Pakistan we have the negative sign of ATM which shows that as the ATM increases the people prefer not to hold money in their hands. Finally, card incorporates the two previous effects because cards are both used to withdraw money at ATMs and to carry on transactions at the point of sales. Their sign will depend on which one of the two mentioned effects dominates. In case of Pakistan cards are negatively related to the demand for money.

\subsection{Results of Model II:}

\section{Estimated Co-integrated Coefficients:}

Dependent variable: Ygap

\begin{tabular}{|c|c|c|c|}
\hline Variables & Coefficients & Std. Error & T Statistics \\
\hline $\mathrm{C}$ & 4.631702 & 0.050341 & 92.0124 \\
\hline $\boldsymbol{e}_{i t-1}$ & 0.183301 & 0.757109 & 0.242107 \\
\hline
\end{tabular}

The above results specify the output gap as a function of the lagged disequilibrium in the money market (or eit-1). According to the expectation our results show that the lagged disequilibrium in the money market leads to wider output gap. 


\section{Conclusion:}

The main objective of our study is to check the effect of financial innovation on money demand and to analyze the impact of money market disequilibrium on output gap.

In order to get these objectives we first test the stationarity of variables by using the ADF test and come to the conclusion that all variables are stationary at first difference except the output gap which is stationary at level. After the confirmation of ADF result we use the cointegration technique for our first model and concluded that both the numbers of ATM and cards are negatively related to the demand for money. So in order to control the money demand we should increase the ATMs. The results also confirms that there exist a quantity theory i.e. $\gamma_{3}$ is almost equal to one with the inclusion of financial innovation in the money demand function. Our second model is related to the money market disequilibrium and the output gap. The findings of this second model shows that money market disequilibrium leads to wider the output gap. We should try to make the equilibrium in the money market.

\section{REFERENCES:}

[1]. Adam, C. S., (1992), "On the Dynamic Specification of Money Demand in Kenya," Journal of African Economies, Vol. 1, No. 2 (August 1992), pp. 233-70.

[2]. Akoena, S. K. K., (1996), "Error-Correction Models of Money Demand for Ghana,” Legon Economic Studies. No. 9605.

[3]. Arize, Augustine, C. (1995), "Effects of Financial Innovations on the Demand for Money Function: Evidence from Japan," International Economic Journal, Vol. 4, No. 1(Spring 1990).

[4]. Arrau, Patricio and De Gregorio, Jose. (1990). "Financial Innovation and Money Demand: Application to Chile and Mexico." Review of Economics and Statistics. 524530

[5]. Arrau, P., De Gregorio, J., Reinhart, C., Wickham, P., (1995). "The demand for money in developing countries: assessing the role of financial innovation." Journal of Development Economics 46 (2), 317-340.

[6]. Aubry, J., and Nott, L., (2002), "Measuring Transactions Money in a World of Financial Innovation,” Bank of Canada Review

[7]. Bank of Ghana. Several Issues of Annual Report and Statistical Bulletin.

[8]. Central Bureau of Statistics (Statistical Service). Quarterly Digest of Statistics, Various Issues.

[9]. Chow, Gregory C., "On the Long-Run and Short-run Demand for Money," Journal of Political Economy," Vol. 74, No.2 (April 1966), pp. 111-31.

[10]. Dickey, D. A., and Fuller, W. A., (1979), "Distribution of the Estimators for Autoregressive Time Series with a Unit Root," Journal of the American Statistical Association, No. 74.

[11]. Dotsey, Michael, (1985), "The Use of Electronic Funds Transfers to Capture the Effects of Cash Management Practices on the Demand for Demand Deposits. A Note,” Journal of Finance 40, pp 1493-1503.

[12]. Enders, Walter (1995). “Applied Econometric Time Series", 1st Ed. New York: John Wiley and Sons Inc.

[13]. Engle R. and C. W. J. Granger (1987). "Co-Integration and Error Correction: Representation, Estimation and Testing," Econometrica 55

[14]. Fair, Ray C., (1987), "International Evidence on the Demand for Money," The Review of Economics and Statistics, Vol. 69, No. 3 (August 1987), pp. 473-80.

[15]. Glennon, Dennis, and Julia Lane, (1996). "Financial Innovations, New Assets and the Behaviour of Money Demand." Journal of Banking and Finance 20 (1996): 207-225.

[16]. Granger, C. W. J. (1969). "Investigating Causal Relations by Econometrica models and Cross- Spectral Methods", Econometrica pp. 424-438 